\title{
Plasmid Profile and Plasmid Curing of Some Enterobacteriaceae Resistant to Ampicillin Isolated from Food, Human Stool, Chicken Stool in Ekiti State
}

\author{
O. K. Ekundayo* \\ Department of Biology, School of Science Bamidele Olumilua University of Education Science \\ and Technology Ikere Ekiti, Ekiti State, Nigeria \\ *Corresponding author
}

\begin{tabular}{l} 
Ke y w o r d s \\
ESBL, GIT, Gram \\
negative, Gram \\
Positive, \\
Enterobacteriaceae, \\
Beta lactamase, \\
Plasmid profile, \\
Plasmid curing \\
Article Info \\
\hline $\begin{array}{l}\text { Accepted: } \\
\text { 15 December } 2020 \\
\text { Available Online: } \\
\text { 10 January } 2021\end{array}$ \\
\hline
\end{tabular}

This study was conducted to show plasmid profile and plasmid curing procedure and it results to determine if resistance in this study was plasmid mediated or chromosomally mediated. A total of 230 ready to eat food samples were randomly purchased, human stool of apparently healthy human volunteer and sick humans' stool from Federal Teaching Hospital Ido (FTH) and University Teaching Hospital Ado Ekiti in Ekiti State with ethical approval from both institution, Fecal samples were also collected from forty-five (45) white broilers and fifty- nine (59) black layers from different poultry farms in Ekiti state. These samples were collected from Ekiti Central (Ado and Igede), Ekiti North (Ido and Ikole) and Ekiti South (Ikere and Emure). Samples collected were analyzed microbiologically using conventional techniques, antibiotics susceptibility testing by disc diffusion method and Double disc synergy test was used to determine $\beta$-lactamase producing bacterial isolates, the genetic basis of resistance was achieved by plasmid profiling and plasmid curing techniques. Four enteric bacteria, namely Escherichia coli, Klebsiella aerogenes, Salmonella typhi and Proteus vulgaris were isolated from the food, stool samples and majority of the bacterial isolate resistance is either plasmid or chromosomally mediated. The results showed that, some Enterobacteriaceae which include E.coli, Salmonella typhi, Klebsiella aerogens and Proteus vulgaris from food, human and chicken stool was isolated carried plasmid while some did not carry plasmid. Also it shows that some resistance are plasmid mediated while some are chromosomally mediated based on the plasmid curing.

\section{Introduction}

A plasmid is a small, circular piece of DNA that is different than the chromosomal DNA, which is all the genetic material found in an organism's chromosomes. It replicates independently of chromosomal DNA. Plasmids are mainly found in bacteria, but they can also be found in archaea and multicellular organisms. Plasmids usually carry at least one gene, and many of the genes that plasmids carry are beneficial to their host organisms. Although they have separate genes from their hosts, they are not considered to be independent life. 
The study of plasmids is important to Medical Microbiology because plasmids can encode genes for antibiotic resistance or virulence factors. Plasmids can also serve as markers of various bacterial strains when a typing system referred to as plasmid profiling. In this method artificially purified plasma deoxyribonucleic acid species are separated according to molecular size (Mayer 1988)

Curing of this cryptic plasmid from a bacterial strain is a method to substantiate the relationship between genetic trait and carriage of the specific trait in the plasmid. Various method involving chemical and physical agent have been develop to eliminate plasmids. It is the elimination of a plasmid from cell culture by treatment with acridine orange at a concentration insufficient to inhibit chromosome replication but sufficient to inhibit plasmid replication

Enterobacteriaceae is a group of Gramnegative bacteria which are straight rods and usually found in the gastrointestinal tract (GIT). Thus, members of this family are referred to as enteric bacteria. This family is the only representative in the order Enterobacteriales of the class Gammaproteobacteria in the phylum Proteobacteria. Most Gram-negative bacteria include the species of Salmonella, Shigella, Yersinia, Klebsiella, Citrobacter, Enterobacter, Proteus, Serratia and Escherichia and others. Escherichia coli is one of the major enteric bacteria which serves as reservoir for resistance gene (Brinaset al., 2005).

Ampicilin is one of the $\beta$-lactam drugs that has been used to treat bacterial infection and demonstrated activity against bacteria. Most strains of Pseudomonas, Klebsiella and Aerobacter are considered resistant to ampicillin. Additionally, resistance to ampicillin is seen in the species of Enterobacter, Citrobacter, Serratia,
Salmonella, indole-positive Proteus and E. coli. Some of these bacteria have been reported to show resistance to two or more antibiotics (Rahal, 2005).

Multiple drug resistance is a condition enabling a disease-causing organism to resist distinct drugs or chemicals of a wide variety of structure and function targeted at eradicating the organism. Multi-drug resistance in bacteria occurs by the accumulation, on resistance R-plasmids or transposons of genes, with each coding for resistance to a specific agent and /or by the action of multi-drug efflux pumps, each of which can pump out more than one drug type. Multiple drug resistance may also be as a result of enzymes deactivating the drugs and thus reducing their effectiveness of the drug (Bennett, 2008).

ESBLs are known as extended-spectrum $\beta$ lactamases because they are able to hydrolyze a wide range of $\beta$-lactam antibiotics than the simple parent $\beta$-lactamase from which they are derived (Bush, 2008). ESBLs are plasmid mediated enzymes which are frequently found in Enterobacteriaceae especially Escherichia coli (Paterson and Bonomo, 2005). This study will show procedure and result of plasmid profile and plasmid curing of some enterobacteriaceaec isolated from food, human and chicken stool in Ekiti State, Nigeria

\section{Materials and Methods}

\section{Samples collection}

\section{Food samples}

Two hundred and thirty (230) ready-to-eat food samples were randomly purchased from Eateries in Ekiti State. Food samples were purchased in a disposable white plastic. It was transported to the laboratory and analyzed within $1 \mathrm{~h}$ of collection 


\section{Fecal samples}

Stool samples were collected from 54 apparently healthy individuals and 142 patients in Ekiti State University Teaching Hospital, Ado Ekiti and Federal Medical Centre, IdoEkiti. Collection of the samples was achieved with the approval of Ethical Committee in both institutions (Appendices 1 -5). Certified Medical Laboratory Scientist assisted in collecting the samples. Samples were also collected from apparently healthy volunteers by distributing Bijou bottles to them.

Fecal samples were also collected from fortyfive (45) white broilers and fifty- nine (59) black layers from different poultry farms in Ekiti state. These samples were collected from Ekiti Central (Ado and Igede), Ekiti North (Ido and Ikole) and Ekiti South (Ikere and Emure). All the samples collected were analyzed in the Laboratory within $1 \mathrm{hr}$ of collection.Isolated bacteria was characterized and identified using colonial morphology, gram staining technique, biochemical test (Cheesebrough, 2000)

\section{Antibiotics sensitivity testing}

Antibiotics susceptibility testing was performed using the disc diffusion method as described by Clinical Laboratory Standard institute CLSI (2014). Commercially prepared antibiotics disc was obtained from Oxoid (Basingstoke, Hampshire, UK). The antibiotics, their codes and concentration in $\mu \mathrm{g}$ are as follows: Aminoglycosides: Streptomycin (Str, $10 \mu \mathrm{g}$ ), Gentamycin (Gen, $10 \mu \mathrm{g})$, Macrolides: Erythromycin (Ery,5 $\mu \mathrm{g}$ ), Phenicols: Chloramphenicol (Chl, $10 \mu \mathrm{g}$ ), Tetracycline: tetracycline (Tet, $25 \mu \mathrm{g}$ ). $\beta$ lactam drugs: Cloxacillin (Cxc, $5 \mu \mathrm{g}$ ), Penicillin (Pen,10 $\mu \mathrm{g}$ ), Ampicilin (Amp,10 $\mu \mathrm{g}$ ), Amoxicillin (Amx,25 $\mu \mathrm{g}$ ), Augmentin (Aug, $30 \mu \mathrm{g}$ ), Fluoroquinolone: Ofloxacin (Ofl, $5 \mu \mathrm{g}$ ), Nalixidic acid (Nal, 30 $\mathrm{g}$ ), Folate pathway inhibitor: Cotrimazole (Cot, 25 $\mu$ g) and other antibiotics like Nitrofurantoin (Nit, $200 \mu \mathrm{g})$.

Pure colonies on each bacterial isolate were inoculated into $5 \mathrm{ml}$ of sterile peptone water and incubated at $37^{\circ} \mathrm{C}$ for $6 \mathrm{~h}$. The turbidity was adjusted to match 0.5 McFarland standards and it was poured on the surface of solidified Mueller-Hinton agar. The peptone water was allowed to stay on the solidified agar and swirl to allow the bacterial spread on the agar for few seconds and then poured away before the commercially available multi-disk (AB Biodisk) for both grampositive and gram-negative were aseptically placed on the plates respectively. The grampositive disc which include Ampicilin (Amp,

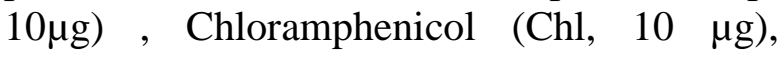
Cloxacillin $\quad(\mathrm{Cxc}, 5 \mu \mathrm{g}), \quad$ Erythromycin (Ery, $5 \mu \mathrm{g})$, Gentamycin (Gen,10 $\mu \mathrm{g})$, Penicillin

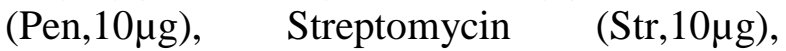

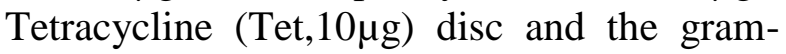
negative disc which include Augmenting

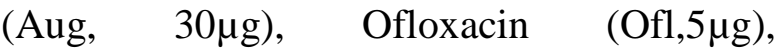

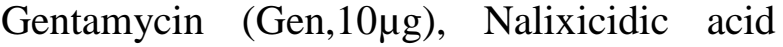

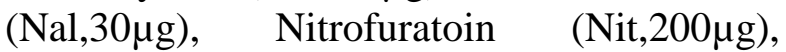
Cotrimazole (Cot, $25 \mu \mathrm{g}), \quad$ Amoxicillin

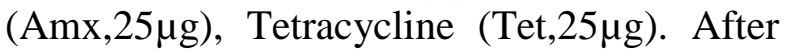
the disc has been aseptically placed on the agar using sterile forceps, the set up was incubated at $37^{\circ} \mathrm{C}$ for $24 \mathrm{~h}$. Zones of inhibition were measured after $24 \mathrm{~h}$ according to CLSI (2014) and organisms were classified as sensitive (S), intermediate (I), resistant (R) and isolates resistant to three or more were classified as multi-drug resistant (MDR) (Ochei and Kolkhtar, 2000)

\section{Detection of ESBL-producing bacterial isolates resistant to Ampicillin using double disk synergy test}

A 20ml portion of sterile Mueller-Hinton agar was poured on a sterile Petri dish and it was allowed to solidify. Isolate was inoculated into $5 \mathrm{ml}$ sterile peptone water. It was 
confirmed with 0.5 McFarland standards before it was poured on the solidified agar plate and swirled to ensure the sample spread through the entire plate before it was poured away. Oxoid single disk consisting of Amoxicillin- Clavulanic acid (30 $\mu \mathrm{g})$, Cefotaxitin (30 $\mu \mathrm{g})$, Ceftriaxone $(30 \mu \mathrm{g})$, Ceftadizime $(30 \mu \mathrm{g})$ were aseptically placed in $20 \mathrm{~mm}$ away from each other on the inoculated plate in such a way that the Amoxillin-Clavulanic acid $(30 \mu \mathrm{g})$ was placed in the middle and it was surrounded with other antibiotics disc. The plate was incubated at $37^{\circ} \mathrm{C}$ for $24 \mathrm{~h}$. The bacteria were considered to be producing ESBL when the zone of inhibition around any of the extendedspectrum $\beta$-lactamase discs showed a clearcut increase towards the AmoxicillinClavulanic acid disc (Ezekiel et al., 2011, Ekundayo O.K and Onifade A.K, 2020).

\section{Genetic characterization of ESBL- producing bacterial isolates resistant to ampicillin byplasmid profiling techniques. Plasmid analysis}

Plasmid analysis was carried out on bacterial isolates that are resistant to ampicillin also produces $\beta$-lactamase. This was carried out in order to know the molecular basis of resistance in some bacterial isolates. This was achieved with the help of Molecular Biology Laboratory of Nigeria Institute of Medical Research (NIMR), Yaba, Lagos, Nigeria

\section{Plasmid extraction}

A $1.5 \mathrm{ml}$ portion of overnight culture was spinned at 12,000rpm for 1 min using a Micro centrifuge and the supernatant was decanted. A total of $300 \mu \mathrm{l}$ of TENS $(25 \mathrm{mM}$ Tris, $10 \mathrm{mM}$ EDTA (Ethylene diaminetetraacetic acid), $\mathrm{NaOH}$ (0.1 Sodium hydroxide) and SDS ( $0.5 \%$ sodium dodecyclsulphate) was added and then mixed together until it became sticky. A portion of $150 \mu \mathrm{l}$ of $3.0 \mathrm{M}$ sodium acetate ( $\mathrm{pH}$ 5.2) was added and the tube vortexes till it was completely mixed. The mixture was micro-centrifuged for $5 \mathrm{~min}$ at 13,000rpm to pellet i.e. (small particles created by compressing the original) cell debris and chromosomal DNA. Supernatant was transferred into a fresh tube (Eppendorf tube) and then mix with $800 \mu 1$ ice cold absolute ethanol and then centrifuged for $10 \mathrm{~min}$ to pellet plasmid DNA. The supernatant was discarded and the pellet was rinsed twice with $1 \mathrm{ml}$ of $70 \%$ ice cold ethanol and dried at $45^{\circ} \mathrm{C}$ for $15 \mathrm{~min}$. The dried pellet was re-suspended in 20-40 $\mu 1$ of TE (Tris and EDTA) buffer and stored at $4{ }^{\circ} \mathrm{C}$ for further use (Ezekiel et al, 2011, Ekundayo and Onifade, 2020)

\section{Agarose gel electrophoresis}

Agarose Gel Electrophoresis is a separation method that can be used to separate DNA based on their molecular weight. The concentration of Agarose used is dependent on the size of DNA to be separated but $0.8 \%$ Agarose is basically used for plasmid DNA. A $0.8 \mathrm{~g}$ portion of Agarose powder was mixed with 100mls of 1X TBE (Tris, Boric acid and EDTA) buffer. The mixture was dissolved by boiling on a hot plate using a magnetic stirrer, and later allowed to cool after which $10 \mu \mathrm{l}$ $(0.001 \mathrm{ml})$ of ethidium bromide was added. The mixture was poured on electrophoresis tank with comb in place to obtain a gel thickness and to avoid bubbles. It was allowed to solidify. The combs were removed and placed with the tray in the electrophoresis tank. 1X TBE (Tris base, Boric acid and EDTA) buffer was poured into the tank to ensure that the buffer covered the surface of the gel. A $15 \mu$ l portion of plasmid DNA was mixed with $2 \mu 1$ of loading dye was carefully loaded onto the well created by combs. Electrode was connected to the power pack in such a way that the negative terminal was at the end where the samples were loaded. 
Electrophoresis was run at $60-100 \mathrm{~V}$ until the loading dye (i.e. bromocresol purple) had migrated about three-quarter of the gel and the electrode was turned off. DNA bands were visualized and photograph using BioRad, Mini-Sub Get GT. The molecular weight of unknown plasmid DNA was extrapolated using the band mobilities in the gel (Ezekiel et al, 2011, Ekundayo and Onifade, 2020)

\section{Curing of plasmid DNA}

Curing of the plasmid was done to determine whether or not a plasmid encodes a trait that codes for antibiotics resistance or multiple antibiotic resistance. Curing was done using the sodium dodecyl sulphate (SDS). The isolate that showed resistance to Ampicillin and those that showed multiple resistance to different antibiotics due to plasmid bands were subjected to plasmid curing.

One gram of sodium dodecyl sulphate (SDS) was added to $100 \mathrm{ml}$ of nutrient broth. The solution was autoclaved at $121^{\circ} \mathrm{C}$ at $15 \mathrm{psi}$ for $15 \mathrm{~min}$. An overnight culture of the sample was standardized according to $0.5 \mathrm{McFarland}$ standard and $0.5 \mathrm{ml}$ from the standardize solution was pipette using Pasteur pipette into the $100 \mathrm{ml}$ sterile nutrient broth. This solution was incubated at $37^{\circ} \mathrm{C}$ for $24 \mathrm{~h}$. After incubation, the isolate was re-inoculated into a sterile nutrient broth and incubated for $24 \mathrm{~h}$ (Annika et al., 2013, Ekundayo and Onifade, 2020)

\section{Post curing sensitivity testing}

The plasmid-cured isolates were tested against those antibiotics to which they were previously resistant.

The diameter of zone of inhibition was measured using metre rule in $\mathrm{mm}$ and the zones were compared with Standard antibiotics chart (Ochei and Kolkhtar, 2000).

\section{Statistical analysis of data}

Data obtained from the study were subjected to analysis of variance (ANOVA) and treatment means were separated by Duncan's New Multiple Range Test using Statistical Analysis System Software (SAS) version 5.0.1.

\section{Results and Discussion}

Based on this research four major member of Enterobacteriaceae were isolated and they include E.coli, Salmonella typhi, Klebsiella aerogene and Proteus vulgaris .

Table 1 shows the antibiotics sensitivity test of the bacterial isolates to 16 antibiotics. All the bacterial isolates are highly sensitive to Ofloxacin, Gentamycin, Nalidixic, Cotrimazole and Nitrofurantoin . Escherichia coli shows highest sensitivity to Nitrofurantoin $\left(82.16 \pm 0.01^{\mathrm{a}}\right)$, Nalidixic acid $\left(81.53 \pm 0.01^{\mathrm{b}}\right)$ and lowest sensitivity to Erythromycin $\left(2.50 \pm 0.01^{\mathrm{g}}\right)$ and Ampicillin $\left(3.83 \pm 0.01^{\mathrm{f}}\right)$. Salmonella typhi was highly sensitive to Nalidixic acid $\left(67.5 \pm 0.01^{\mathrm{a}}\right)$ and the lowest in Cloxacillin $\left(0.00 \pm 000^{\mathrm{f}}\right)$. Klebsiella aerogenes had highest sensitivity to Nalidixic acid $\left(77.4 \pm 0.01^{\mathrm{a}}\right)$ and Gentamycin $\left(74.2 \pm 0.01^{\mathrm{b}}\right)$ and the lowest in Erythromycin $\left(6.45 \pm 004^{\mathrm{f}}\right)$ and Tetracycline $\left(6.4 \pm 0.01^{\mathrm{h}}\right)$. Proteus vulgaris had highest sensitivity to Nalidixic acid $\left(78.72 \pm 0.01^{\mathrm{a}}\right)$ and the lowest sensitivity in Ampicillin $\left(4.24 \pm 0.01^{\mathrm{e}}\right)$.

Table2 shows the percentage resistance of bacterial isolates from fecal to antibiotics. Escherichia coli was highly resistant to Ampicillin $\left(92.68 \pm 0.01^{\mathrm{a}}\right)$ and lowest resistant to was seen in Nalidixic acid $\left(15.92 \pm 0.01^{\mathrm{g}}\right)$. Highest resistant to Salmonella typhi was seen in Cloxacillin $\left(95.0 \pm 0.01^{\mathrm{a}}\right)$ and lowest resistant to Salmonella typhi in Ofloxacin $\left(22.5 \pm 0.07^{\mathrm{g}}\right)$. Klebsiella aerogenes was highly resistant to Cloxacillin $\left(90.33 \pm 0.01^{\mathrm{a}}\right)$ 
and lowest resistant in Gentamycin $\left(25.8 \pm 0.01{ }^{\mathrm{f}}\right)$. Also, Proteus vulgaris had highest resistant to antibiotics in Ampicillin $\left(97.75 \pm 0.01^{\mathrm{a}}\right)$ and lowest resistant to Proteus vulgaris was seen in Nitrofuratoin (21.28 $\left.\pm 0.01^{\mathrm{h}}\right)$.

Table 3 shows the multiple resistance of bacterial isolates to different antibiotics. Proteus vulgaris from black layer stool and Salmonella typhi from sick human showed multiple resistance to more than ten (10) different antibiotics. Out of 47 Proteus vulgaris that was isolated across the samples, only $5(10.63 \%)$ isolated from apparently healthy black layers showed multi-drug resistance and out of 40 Salmonella typhi isolated across the sample only 1(2.5\%) from sick human stool showed multi-drug resistance.

The percentage incidence of $\beta$-lactamase producing bacterial isolates in food, human and chicken fecal are represented in Table 4. The percentage of $\beta$ - lactamase producing Escherichia coli was high in food $(45.16 \%)$ and sick human stools (41.94\%) and low in apparently healthy human stool $(6.45 \%)$ and apparently healthy black layers stool $(6.45 \%)$. $\beta$-lactamase producing Salmonella typhi was high in food samples (37.5\%) and apparently healthy layer stool $(12.5 \%)$ while it was low in apparently healthy human stool $(12.5 \%)$ and sick human stool (12.5). Klebsiella aerogenes producing $\beta$-lactamase was high in apparently human stool (40\%) and apparently healthy layers stool $(60 \%)$ and low in food $(0 \%)$ and sick stool (0\%). Proteus vulgaris producing $\beta$-lactamase was high in apparently healthy black layers $(85.71 \%)$, sick human stool $(14.29 \%)$ than food $(0 \%)$ and healthy human stool (0\%).

Plate 1 shows the results of plasmid profile analysis of the multi-drug resistant isolates from apparently healthy black layers MR1, MR2, MR3, MR4 (lane 1-lane 4), MR6 (lane
6) are Proteus vulgaris and MR5 (lane 5) sick human stool (Salmonella typhi). It shows that they have similar plasmid band with molecular weight of about 23,130 bp.

Plate 2, 3, 4, and 5 reveal the plasmid profile of isolated bacteria from apparently healthy black layers, human stool and food samples. Lanes 1-31 are Escherichia coli, lanes 32-38 are Proteus vulgaris while lanes 39-46 are Salmonella typhi and lane 47-51 are Klebsiella aerogenes. Plate 2 shows the plasmid profile of Escherichia coli isolated from sick human stool (lanes 1-13). Escherichia coli in lane 1-13 (Plate 2) isolated from sick human stool with exception in lane 2, 6 and 13 which showed no plasmid while the remaining lanes had similar plasmid with molecular weight of 23,130 bp when compared with Hind III lambda as a molecular marker. However, Escherichia coli in lane 3 has 3 different bands with molecular weights 23,130 bp; 6,557 bp and 2,322 bp. Escherichia coli in lane 14-27 (Plate 3) were isolated from food samples. Escherichia coli from lanes $14,16,18,20,21,22,23,24,25$ have single plasmid band with molecular weight of 23,130 bp except $E$. coli in lanes 15, 17, 19, 26 and 27 which showed no plasmid. Plasmid profile of Escherichia coli isolated from apparently healthy human stool in lanes 28-29 have single plasmid band with molecular weight of 23,130bp while Escherichia coli isolated from apparently healthy black layer in lanes 30 and 31 (Plate 4) showed no plasmid.

Proteus vulgaris isolated from sick human stool in lane 32 have single plasmid band with molecular weight of 23,130 and Proteus vulgaris from apparently healthy black layers in lanes 33-38 (Plate 4) showed similar plasmid of about 23, 130 bp. However, Salmonella typhi isolated from food in lanes 39-41 showed single plasmid band with molecular weight of 23,130bp. Also, Salmonella typhi isolated from apparently 
healthy human (lane 42), sick human (lane 43) and apparently healthy black layer ( lanes 44-46) (Plate 4) have similar plasmid with molecular weight of about 23, 130bp when compare with hind III lambda used as a molecular marker with the exception in lane 39 and 46 which showed no plasmid.

The plasmid profile of Klebsiella aerogenes isolated from feces apparently healthy human (lanes 47-48) and apparently healthy black layer (lanes 49-51) in Plate 5 showed single plasmid band with molecular weight of 23,130 bp with exception seen in lane 47 which showed no plasmid. Plate 6 shows the ESBL producing bacterial isolate synergy) with Amoxicillin-clavulanic acid, Cefoxitin and Ceftriaxone.

Table 5 represents the pre and post curing sensitivity of some bacterial isolates showing multiple resistance to antibiotics. Multidrug resistant Proteus vulgaris 1(MRP1) isolated from black layers was resistant to 12 commonly prescribed antibiotics except Nalixidic acid. MRP1 were resistance to Ampicillin ${ }^{\mathrm{R}}$, Chloramphenicol ${ }^{\mathrm{R}}$, Cloxacillin ${ }^{\mathrm{R}}$, Erythromycin ${ }^{\mathrm{R}}$, Penicillin ${ }^{\mathrm{R}}$, Streptomycin ${ }^{\mathrm{R}}$, Tetracycline ${ }^{\mathrm{R}}$, Augumentin ${ }^{\mathrm{R}}$, Ofloxacin ${ }^{\mathrm{R}}$, Nitrofuratoin $^{\mathrm{R}}$, Amoxicillin ${ }^{\mathrm{R}}$, Tetracycline ${ }^{\mathrm{R}}$ before plasmid was cured while post sensitivity of MRP1 was also resistance to all the antibiotics (Ampicillin $\mathrm{R}$, Chloramphenicol R, Cloxacillin R', Erythromycin ${ }^{\mathrm{R}}$, Penicillin ${ }^{\mathrm{R}}$, Streptomycin ${ }^{\mathrm{R}}$, Tetracycline R, Augumentin ${ }^{\mathrm{R}}$, Ofloxacin ${ }^{\mathrm{R}}$, Nitrofuratoin ${ }^{\mathrm{S}}$, Amoxicillin ${ }^{\mathrm{R}}$, Tetracycline ${ }^{\mathrm{R}}$. This shows that the resistance was not plasmid mediated but it is chromosomal mediated. Multidrug resistant Proteus vulgaris (MRP2) was resistant to 12 commonly prescribed antibiotics except Nalixidic acid (Ampicillin ${ }_{\mathrm{R}}^{\mathrm{R}}$, Chloramphenicol R, Cloxacillin R', Erythromycin R, Penicillin R, Streptomycin R', Tetracycline R, Augumentin ${ }^{\mathrm{R}}$, Ofloxacin ${ }^{\mathrm{R}}$,
Nitrofuratoin ${ }^{\mathrm{R}}$, Amoxicillin ${ }^{\mathrm{R}}$, Tetracycline ${ }^{\mathrm{R}}$ before plasmid cured while after plasmid curing, MRP2 was sensitive to 10 antibiotics (Ampicillin ${ }^{\mathrm{S}}$, Chloramphenicol ${ }^{\mathrm{S}}$ Cloxacillin S, Erythromycin S, Penicillin S, Streptomycin, Tetracycline s, Augumentin's, Ofloxacins, Nitrofuratoin ${ }^{\mathrm{S}}$, Amoxicillin ${ }^{\mathrm{R}}$, Tetracycline ${ }^{\mathrm{R}}$ ) . This shows that the resistance to antibiotics is plasmid mediated.

Multidrug resistant Proteus vulgaris (MRP3) was resistant to 12 commonly prescribed antibiotics except Amoxicillin (Ampicillin R, Chloramphenicol R, Cloxacillin R', Erythromycin R, Penicillin R , Streptomycin R', Tetracycline R, Augumentin ${ }^{\mathrm{R}}$, Ofloxacin ${ }^{\mathrm{R}}$, Nitrofuratoin ${ }^{R}$, Nalixidic acid ${ }^{R}$, tetracycline ${ }^{\mathrm{R}}$ before plasmid curing while after plasmid curing, MRP3 was sensitive to 10 antibiotics (Ampicillin ${ }^{\mathrm{S}}$, Chloramphenicol ${ }^{\mathrm{S}}$ Cloxacillin s, Erythromycin s, Penicillin S, Streptomycin, Tetracycline S, Augumentins, Ofloxacins', Nitrofuratoin ${ }^{\mathrm{S}}$, Nalixidic acid ${ }^{\mathrm{S}}$, Tetracycline

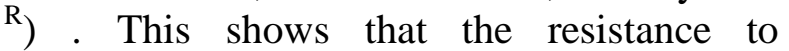
antibiotics is plasmid mediated.

Multidrug resistant Proteus vulgaris (MRP4) was resistant to 12 commonly prescribed antibiotics except Amoxicillin (Ampicillin R, Chloramphenicol R, Cloxacillin R, Erythromycin R, Penicillin R, Streptomycin R', Tetracycline R, Augumentin ${ }^{\mathrm{R}}$, Ofloxacin ${ }^{\mathrm{R}}$, Nitrofuratoin ${ }^{\mathrm{R}}$, Nalixidic acid ${ }^{\mathrm{R}}$, Tetracycline ${ }^{\mathrm{R}}$ before plasmid curing while after curing, MRP4 was sensitive to 10 antibiotics (Ampicillin ${ }^{\mathrm{S}}$, Chloramphenicol ${ }^{\mathrm{S}}$ Cloxacillin S, Erythromycin S, Penicillin S, Streptomycin, Tetracycline s, Augumentin's, Ofloxacins, Nitrofuratoin ${ }^{\mathrm{S}}$, Nalixidic acid ${ }^{\mathrm{S}}$, Tetracycline S) . This shows that the resistance to antibiotics is plasmid mediated.

Multidrug resistant Salmonella typhi (MRS2) was resistant to 12 commonly prescribed antibiotics except Nitrofuratoin (Ampicillin ${ }^{\mathrm{R}}$, Chloramphenicol R, Cloxacillin R', 
Erythromycin ${ }^{\mathrm{R}}$, Penicillin ${ }^{\mathrm{R}}$, Streptomycin ${ }^{\mathrm{R}}$, Tetracycline R, Augumentin ${ }^{R}$, Ofloxacin ${ }^{R}$, Nalixidic acid $^{\mathrm{R}}$, Amoxicillin ${ }^{\mathrm{R}}$, Tetracycline ${ }^{\mathrm{R}}$ before plasmid curing while after plasmid curing of MRP2 was sensitive to 10antibioitcs (Ampicillin ${ }^{\mathrm{R}}$, Chloramphenicol ${ }^{\mathrm{R}}$ Cloxacillin ${ }^{\mathrm{R}}$, Erythromycin ${ }^{\mathrm{R}}$, Penicillin ${ }^{\mathrm{R}}$, Streptomycin ${ }^{R}$, Tetracycline ${ }^{R}$, Augumentin ${ }^{\mathrm{R}}$, Ofloxacin ${ }^{\mathrm{R}}$, Nitrofuratoin ${ }^{\mathrm{R}}$, Amoxicillin ${ }^{\mathrm{R}}$, Tetracycline $\mathrm{R})$. The resistance is not plasmid mediated but chromosomal.

Multidrug resistant Proteus vulgaris (MRP6) was resistant to 12 commonly prescribed antibiotics except Nalixidic acid (Ampicillin R, Chloramphenicol R, Cloxacillin R, Erythromycin R, Penicillin $^{\mathrm{R}}$, Streptomycin R', Tetracycline R, Augumentin ${ }^{\mathrm{R}}$, Ofloxacin ${ }^{\mathrm{R}}$, Nitrofuratoin ${ }^{\mathrm{R}}$, Nalixidic acid ${ }^{\mathrm{R}}$, Tetracycline ${ }^{\mathrm{R}}$ before plasmid curing while after plasmid was cured, MRP6 was sensitive to 10 antibiotics (Ampicillin $\mathrm{S}$, Chloramphenicol $\mathrm{S}$ Cloxacillin S, Erythromycin S, Penicillin S, Streptomycin, Tetracycline S, Augumentin', Ofloxacin $^{\mathrm{S}}$, Nitrofuratoin ${ }^{\mathrm{S}}$ ). This shows that resistance to antibiotics is plasmid mediated.

Table 6 represents the pre and post curing sensitivity of bacterial isolates from food, human and chicken (black layers) that were resistant to Ampicillin. Escherichia coli (E1,E3, E4,E5, E8, E9, E11, and E12 isolated from sick human being were resistant to Ampicillin ${ }^{\mathrm{R}}$ before curing while after curing, E1,E3, E4,E5, E8, E9, E11, and E12 were sensitive to Ampicillin $\mathrm{S}$. It shows that the resistance to antibiotics is plasmid mediated. Escherichia coli E7 and E10 isolated from sick human being were resistant to Ampicillin ${ }^{\mathrm{R}}$ before plasmid curing while after curing E7 and E10 were resistant to Ampicillin ${ }^{\mathrm{R}}$. The resistance to antibiotics is not plasmid mediated but rather chromosomal mediated. Escherichia coli E14, E15, E18, E20, and E22, isolated from food samples were resistant to Ampicillin ${ }^{\mathrm{R}}$ before plasmid curing while after plasmid curing E14, E15, E18, E20, and E22 were sensitive to Ampicillin $\mathrm{S}$ this shows that resistance to antibiotics is plasmid mediated. Escherichia coli E16, E21, E23, E24 and E25 isolated from food samples were resistant to Ampicillin ${ }^{\mathrm{R}}$ before curing while after curing E16, E21, E23, E24 and E25 were resistant to Ampicillin ${ }^{\mathrm{R}}$ after curing this shows that the resistance to antibiotics is not plasmid mediated (chromosomal).

Escherichia coli E28 and E29 isolated from healthy human being were resistant to Ampicillin ${ }^{\mathrm{R}}$ before plasmid curing while after plasmid curing E28 and E29 were sensitive to Ampicillin $\mathrm{S}$. This signifies that resistance to antibiotics is plasmid mediated.

Proteus vulgaris $\mathrm{P} 32$ (sick human stool), P33, P34, P35, P37, P38 (apparently healthy black layer faeces) were resistant to Ampicillin ${ }^{R}$ before plasmid curing while after plasmid curing P32, P33, P34, P35,P37,P38 were sensitive to Ampicillin $\mathrm{S}$. Resistance to antibiotics is plasmid mediated. Only P36 was resistant to ampicillin and after curing it was still resistant to Ampicillin. This shows that the resistant to antibiotics is chromosomal mediated.

Salmonella typhi S40, S41 isolated from food samples), S42 from sick human stool, S44 and S45 from apparently healthy black layer were resistant to Ampicillin $\mathrm{R}$ and Chloramphenicol ${ }^{\mathrm{R}}$ before plasmid curing while after plasmid curing S40 and S41 were sensitive Ampicillin $\mathrm{S}$. The resistance to antibiotics is plasmid mediated. Salmonella typhi S43 from sick human stool was resistant to Ampicillin ${ }^{\mathrm{R}}$ and Chloramphenicol ${ }^{\mathrm{R}}$ before curing while after curing S43 was resistant to Ampicillin ${ }^{\mathrm{R}}$. This shows that resistance to antibiotics is not plasmid mediated (chromosomal). 
Klebsiella aerogenes K48, K49, K50, K51 isolated from apparently healthy black layers were resistant Ampicillin ${ }^{\mathrm{R}}$ before curing while after curing K48, K49, K50, K51 were sensitive to ampicillin $\mathrm{S}$. This shows that resistance to antibiotics is plasmid mediated.

Table.1 Percentage of sensitive bacterial isolates from fecal to antibiotics

\begin{tabular}{|l|l|l|l|l|}
\hline Antibiotics $(\mu \mathrm{g})$ & $\begin{array}{l}\text { Escherichia } \\
\text { coli }\end{array}$ & $\begin{array}{l}\text { Salmonella } \\
\text { typhi }\end{array}$ & $\begin{array}{l}\text { Klebsiella } \\
\text { aerogenes }\end{array}$ & $\begin{array}{l}\text { Proteus } \\
\text { Vulgaris }\end{array}$ \\
\hline Ampicillin & $3.83 \pm 0.01^{\mathrm{f}}$ & $5.00 \pm 0.14^{\mathrm{e}}$ & $16.13 \pm 0.01^{\mathrm{c}}$ & $4.24 \pm 0.01^{\mathrm{e}}$ \\
\hline Chloramphenicol & $5.73 \pm 0.01^{\mathrm{d}}$ & $35.0 \pm 0.01^{\mathrm{c}}$ & $25.81 \pm 0.01^{\mathrm{b}}$ & $17.02 \pm 0.01^{\mathrm{c}}$ \\
\hline Cloxacillin & $4.50 \pm 0.07^{\mathrm{e}}$ & $0.00 \pm 000^{\mathrm{f}}$ & $9.67 \pm 0.01^{\mathrm{e}}$ & $10.64 \pm 0.01^{\mathrm{d}}$ \\
\hline Erythromycin & $2.50 \pm 0.01^{\mathrm{g}}$ & $2.5 \pm 001^{\mathrm{g}}$ & $6.45 \pm 004^{\mathrm{f}}$ & $10.64 \pm 0.01$ \\
\hline Gentamycin & $70.1 \pm 0.09^{\mathrm{a}}$ & $57.5 \pm 017^{\mathrm{a}}$ & $74.2 \pm 001^{\mathrm{a}}$ & $57.45 \pm 0.02^{\mathrm{a}}$ \\
\hline Penicillin & $6.40 \pm 0.07^{\mathrm{c}}$ & $7.5 \pm 0.01^{\mathrm{e}}$ & $6.5 \pm 001^{\mathrm{f}}$ & $17.02 \pm 0.01^{\mathrm{c}}$ \\
\hline Streptomycin & $12.74 \pm 0.01^{\mathrm{b}}$ & $12.5 \pm 0.01^{\mathrm{d}}$ & $12.90 \pm 0.01^{\mathrm{d}}$ & $4.3 \pm 0.07^{\mathrm{e}}$ \\
\hline Tetracycline & $5.73 \pm 0.01^{\mathrm{d}}$ & $37.50 \pm 0.01^{\mathrm{b}}$ & $6.45 \pm 0.02^{\mathrm{f}}$ & $20.53 \pm 0.01^{\mathrm{b}}$ \\
\hline Augmentin & $14.96 \pm 0.01^{\mathrm{g}}$ & $12.5 \pm 001^{\mathrm{g}}$ & $12.90 \pm 0.01^{\mathrm{g}}$ & $8.00 \pm 0.01^{\mathrm{h}}$ \\
\hline Ofloxacin & $60.19 \pm 0.01^{\mathrm{e}}$ & $62.5 \pm 0.01^{\mathrm{c}}$ & $61.29 \pm 0.01^{\mathrm{d}}$ & $46.81 \pm 0.01^{\mathrm{e}}$ \\
\hline Gentamycin & $70.1 \pm 0.09^{\mathrm{e}}$ & $57.5 \pm 0.17^{\mathrm{d}}$ & $74.2 \pm 0.01^{\mathrm{b}}$ & $57.45 \pm 0.02^{\mathrm{c}}$ \\
\hline Nalidixic & $81.53 \pm 0.01^{\mathrm{b}}$ & $67.5 \pm 0.01^{\mathrm{a}}$ & $77.4 \pm 0.01^{\mathrm{a}}$ & $68.10 \pm 0.01^{\mathrm{b}}$ \\
\hline Nitrofurantoin & $82.16 \pm 0.01^{\mathrm{a}}$ & $65 \pm 0.07^{\mathrm{b}}$ & $64.5 \pm 0.01^{\mathrm{c}}$ & $78.72 \pm 0.01^{\mathrm{a}}$ \\
\hline Cotrimazole & $60.50 \pm 001^{\mathrm{d}}$ & $57.5 \pm 001^{\mathrm{d}}$ & $45.16 \pm 001^{\mathrm{e}}$ & $48.94 \pm 0.01^{\mathrm{d}}$ \\
\hline Amoxicillin & $20.06 \pm 001^{\mathrm{f}}$ & $25.0 \pm 0.01^{\mathrm{f}}$ & $16.13 \pm 0.01^{\mathrm{f}}$ & $17.02 \pm 0.01^{\mathrm{g}}$ \\
\hline Tetracycline & $5.73 \pm 0.01^{\mathrm{h}}$ & $37.50 \pm 0.01^{\mathrm{e}}$ & $6.4 \pm 0.01^{\mathrm{h}}$ & $25.53 \pm 0.01^{\mathrm{f}}$ \\
\hline
\end{tabular}

Table.2 Percentage resistance of bacterial isolates from fecal to antibiotics

\begin{tabular}{|l|l|l|l|l|}
\hline Antibiotics( $\mu \mathrm{g})$ & $\begin{array}{l}\text { Escherichia } \\
\text { coli }\end{array}$ & $\begin{array}{l}\text { Salmonella } \\
\text { typhi }\end{array}$ & $\begin{array}{l}\text { Klebsiella } \\
\text { aerogenes }\end{array}$ & $\begin{array}{l}\text { Proteus } \\
\text { vulgaris }\end{array}$ \\
\hline Ampicillin & $92.68 \pm 0.01^{\mathrm{a}}$ & $82.5 \pm 0.14^{\mathrm{d}}$ & $83.87 \pm 0.01^{\mathrm{c}}$ & $97.75 \pm 0.01^{\mathrm{a}}$ \\
\hline Chloramphenicol & $80.85 \pm 0.04^{\mathrm{f}}$ & $65.0 \pm 0.01^{\mathrm{f}}$ & $70.96 \pm 0.01^{\mathrm{e}}$ & $80.85 \pm 0.03^{\mathrm{c}}$ \\
\hline Cloxacillin & $85.98 \pm 0.01^{\mathrm{d}}$ & $95.0 \pm 0.01^{\mathrm{a}}$ & $90.33 \pm 0.01^{\mathrm{a}}$ & $78.7 \pm 0.01^{\mathrm{d}}$ \\
\hline Erythromycin & $86.35 \pm 0.01^{\mathrm{c}}$ & $87.5 \pm 0.01^{\mathrm{c}}$ & $87.10 \pm 0.01^{\mathrm{b}}$ & $89.36 \pm 0.01^{\mathrm{b}}$ \\
\hline Gentamycin & $27.7 \pm 0.09^{\mathrm{g}}$ & $30.0 \pm 0.10^{\mathrm{h}}$ & $25.8 \pm 0.01^{\mathrm{f}}$ & $31.91 \pm 0.01^{\mathrm{g}}$ \\
\hline Penicillin & $82.17 \pm 0.01^{\mathrm{e}}$ & $90 \pm 0.14^{\mathrm{b}}$ & $87.09 \pm 0.01^{\mathrm{b}}$ & $80.85 \pm 0.01^{\mathrm{c}}$ \\
\hline Streptomycin & $82.17 \pm 0.01^{\mathrm{e}}$ & $70 \pm 0.01^{\mathrm{e}}$ & $83.87 \pm 0.01^{\mathrm{c}}$ & $68.08 \pm 0.01^{\mathrm{f}}$ \\
\hline Tetracycline & $88.85 \pm 0.01^{\mathrm{b}}$ & $50 \pm 0.01^{\mathrm{g}}$ & $77.42 \pm 0.01^{\mathrm{d}}$ & $70.21 \pm 0.01^{\mathrm{e}}$ \\
\hline Augmentin & $71.65 \pm 0.02^{\mathrm{c}}$ & $77.5 \pm 0.05^{\mathrm{a}}$ & $74.17 \pm 0.01^{\mathrm{b}}$ & $91.5 \pm 0.01^{\mathrm{a}}$ \\
\hline Ofloxacin & $34.71 \pm 0.01^{\mathrm{d}}$ & $22.5 \pm 0.07^{\mathrm{g}}$ & $32.26 \pm 0.01^{\mathrm{e}}$ & $38.30 \pm 0.01^{\mathrm{e}}$ \\
\hline Gentamycin & $27.7 \pm 0.09^{\mathrm{e}}$ & $30.0 \pm 0.10^{\mathrm{e}}$ & $25.8 \pm 0.06^{\mathrm{f}}$ & $31.91 \pm 0.01^{\mathrm{f}}$ \\
\hline Nalidixic & $15.92 \pm 0.01^{\mathrm{g}}$ & $27.5 \pm 0.07^{\mathrm{f}}$ & $12.90 \pm 0.01^{\mathrm{g}}$ & $27.66 \pm 0.01^{\mathrm{g}}$ \\
\hline Nitrofurantoin & $16.24 \pm 0.01^{\mathrm{f}}$ & $27.5 \pm 0.07^{\mathrm{f}}$ & $32.25 \pm 0.04^{\mathrm{e}}$ & $21.28 \pm 0.01^{\mathrm{h}}$ \\
\hline Cotrimazole & $34.71 \pm 0.01^{\mathrm{d}}$ & $35.0 \pm 0.14^{\mathrm{d}}$ & $41.94 \pm 0.01^{\mathrm{d}}$ & $40.42 \pm 0.01^{\mathrm{d}}$ \\
\hline Amoxicillin & $77.29 \pm 0.01^{\mathrm{b}}$ & $75 \pm 0.01^{\mathrm{b}}$ & $54.83 \pm 0.01^{\mathrm{c}}$ & $76.59 \pm 0.01^{\mathrm{b}}$ \\
\hline Tetracycline & $88.85 \pm 0.01^{\mathrm{a}}$ & $50 \pm 0.07^{\mathrm{c}}$ & $77.42 \pm 0.01^{\mathrm{a}}$ & $70.21 \pm 0.01^{\mathrm{c}}$ \\
\hline
\end{tabular}


Table.3 Multiple resistance of bacterial isolates to different antibiotics

\begin{tabular}{|c|c|c|c|c|c|c|c|c|c|c|c|c|c|c|c|c|c|}
\hline \multirow{2}{*}{$\begin{array}{l}\text { Bacteria } \\
\text { Isolates }\end{array}$} & \multirow{2}{*}{$\begin{array}{l}\text { Sources of } \\
\text { samples }\end{array}$} & \multicolumn{8}{|c|}{ Gram-positive disc } & \multicolumn{8}{|c|}{ Gram-negative disc } \\
\hline & & Amp & Chl & $\mathrm{Cxc}$ & Ery & Gen & Pen & Str & Tet & Aug & Ofl & Gen & Nit & Nal & Cot & Am & Tet \\
\hline $\begin{array}{l}\text { Proteus } \\
\text { vulgaris }\end{array}$ & $\begin{array}{l}\text { Black layer } \\
\text { stool }\end{array}$ & $\mathrm{R}$ & $\mathrm{R}$ & $\mathrm{R}$ & $\mathrm{R}$ & $\mathrm{S}$ & $\mathrm{R}$ & $\mathrm{R}$ & $\mathrm{R}$ & $\mathrm{R}$ & $\mathrm{R}$ & $\mathrm{S}$ & $\mathrm{R}$ & $S$ & $\mathrm{~S}$ & $\mathrm{R}$ & $\mathrm{R}$ \\
\hline $\begin{array}{l}\text { Proteus } \\
\text { vulgaris }\end{array}$ & $\begin{array}{l}\text { Black layer } \\
\text { stool }\end{array}$ & $\mathrm{R}$ & $\mathrm{R}$ & $\mathrm{R}$ & $\mathrm{R}$ & $S$ & $\mathrm{R}$ & $\mathrm{R}$ & $\mathrm{R}$ & $\mathrm{R}$ & $\mathrm{R}$ & $\mathrm{S}$ & $\mathrm{R}$ & $S$ & $S$ & $\mathrm{R}$ & $\mathrm{R}$ \\
\hline $\begin{array}{l}\text { Proteus } \\
\text { vulgaris }\end{array}$ & $\begin{array}{l}\text { Black layer } \\
\text { stool }\end{array}$ & $\mathrm{R}$ & $\mathrm{R}$ & $\mathrm{R}$ & $\mathrm{R}$ & S & $\mathrm{R}$ & $\mathrm{R}$ & $\mathrm{R}$ & $\mathrm{R}$ & $\mathrm{R}$ & $\mathrm{S}$ & $\mathrm{R}$ & $\mathrm{R}$ & $\mathbf{S}$ & $\mathbf{S}$ & $\mathrm{R}$ \\
\hline $\begin{array}{l}\text { Proteus } \\
\text { vulgaris }\end{array}$ & $\begin{array}{l}\text { Black layer } \\
\text { stool }\end{array}$ & $\mathrm{R}$ & $\mathrm{R}$ & $\mathrm{R}$ & $\mathrm{R}$ & S & $\mathrm{R}$ & $\mathrm{R}$ & $\mathrm{R}$ & $\mathrm{R}$ & $\mathrm{R}$ & $\mathrm{S}$ & $\mathrm{R}$ & $\mathrm{R}$ & $\mathbf{S}$ & $\mathbf{S}$ & $\mathrm{R}$ \\
\hline $\begin{array}{l}\text { Salmonella } \\
\text { typhi }\end{array}$ & $\begin{array}{l}\text { Sick Human } \\
\text { stool }\end{array}$ & $\mathrm{R}$ & $\mathrm{R}$ & $\mathrm{R}$ & $\mathrm{R}$ & S & $\mathrm{R}$ & $\mathrm{R}$ & $\mathrm{R}$ & $\mathrm{R}$ & $\mathrm{R}$ & $\mathrm{S}$ & S & $\mathrm{R}$ & S & $\mathrm{R}$ & $\mathrm{R}$ \\
\hline $\begin{array}{l}\text { Proteus } \\
\text { vulgaris }\end{array}$ & $\begin{array}{l}\text { Black layer } \\
\text { stool }\end{array}$ & $\mathrm{R}$ & $\mathrm{R}$ & $\mathrm{R}$ & $\mathrm{R}$ & $S$ & $\mathrm{R}$ & $\mathrm{R}$ & $\mathrm{R}$ & $\mathrm{R}$ & $\mathrm{R}$ & $\mathrm{S}$ & $\mathrm{R}$ & $S$ & $\mathrm{~S}$ & $\mathrm{R}$ & $\mathrm{R}$ \\
\hline
\end{tabular}

R- resistant, S- sensitive, Amp-Ampicilin, Chl- Chloramphenicol, Cxc, Cloxacillin, Ery- Erythromycin, Pen-Penicillin, Str- Streptomycin, Tet- Tetracycline, AugAugumentin, Ofl-Ofloxacin, Nit-Nitrofuratoin, Nal- Nalixidic acid, Amx- Amoxicillin.

Table.4 Percentage incidence of $\beta$-lactamase producing bacteria isolates in food, human and chicken (black layers) stool in Ekiti state

\begin{tabular}{|l|l|l|l|l|}
\hline Samples & $\begin{array}{l}\text { Escherichia } \\
\text { coli }\end{array}$ & $\begin{array}{l}\text { Salmonella } \\
\text { typhi }\end{array}$ & $\begin{array}{l}\text { Klebsiella } \\
\text { aerogenes }\end{array}$ & $\begin{array}{l}\text { Proteus } \\
\text { Vulgaris }\end{array}$ \\
\hline Food & $14(45.16)$ & $3(37.5)$ & $0(0)$ & $0(0)$ \\
\hline Apparently healthy human stool & $2(6.45)$ & $1(12.5)$ & $2(40)$ & $0(0)$ \\
\hline Sick human stool & $13(41.94)$ & $1(12.5)$ & $0(0)$ & $1(14.29)$ \\
\hline $\begin{array}{l}\text { Apparently healthy black layer } \\
\text { stool }\end{array}$ & $2(6.45)$ & $3(37.5)$ & $3(60)$ & $6(85.71)$ \\
\hline
\end{tabular}


Table.5 Pre and post sensitivity curing of multiple drug resistance bacterial isolates from sick human and apparently healthy black layer

\begin{tabular}{|c|c|c|c|c|c|c|c|c|c|c|c|c|c|c|c|c|c|c|c|c|c|c|c|c|}
\hline \multicolumn{25}{|c|}{ Antibiotics ( $\mu \mathrm{g})$} \\
\hline \multirow[t]{2}{*}{ Isolates } & \multicolumn{2}{|c|}{ Amp } & \multicolumn{2}{|l|}{ Chl } & \multicolumn{2}{|l|}{ Cxc } & \multicolumn{2}{|l|}{ Ery } & \multicolumn{2}{|l|}{ Pen } & \multicolumn{2}{|l|}{ Str } & \multicolumn{2}{|l|}{ Tet } & \multicolumn{2}{|l|}{ Aug } & \multicolumn{2}{|l|}{ Ofl } & \multicolumn{2}{|l|}{ Nit } & \multicolumn{2}{|l|}{ Nal } & \multicolumn{2}{|c|}{ Amx } \\
\hline & BC & $\mathbf{A C}$ & BC & $\mathbf{A C}$ & BC & $\mathbf{A C}$ & BC & $\mathbf{A C}$ & BC & $\mathbf{A C}$ & BC & $\mathbf{A C}$ & BC & $\mathbf{A C}$ & BC & AC & BC & AC & BC & AC & BC & $\mathbf{A C}$ & BC & AC \\
\hline MRP1 & $\begin{array}{l}\mathbf{0} \\
\text { (R) }\end{array}$ & $\begin{array}{l}\text { O } \\
\text { (R) }\end{array}$ & $\begin{array}{l}\text { 0 } \\
\text { (R) }\end{array}$ & $\begin{array}{l}\mathbf{0} \\
(\mathbf{R})\end{array}$ & $\begin{array}{l}\mathbf{0} \\
\text { (R) }\end{array}$ & $\begin{array}{l}8.3 \\
(\mathbf{R})\end{array}$ & $\begin{array}{l}\mathbf{0} \\
\text { (R) }\end{array}$ & $\begin{array}{l}\text { O } \\
\text { (R) }\end{array}$ & $\begin{array}{l}\mathbf{0} \\
\text { (R) }\end{array}$ & $\begin{array}{l}\text { 0 } \\
\text { (R) }\end{array}$ & $\begin{array}{l}\mathbf{0} \\
\text { (R) }\end{array}$ & $\begin{array}{l}\mathbf{0} \\
(\mathbf{R})\end{array}$ & $\begin{array}{l}\text { 0 } \\
\text { (R) }\end{array}$ & $\begin{array}{l}\mathbf{0} \\
\text { (R) }\end{array}$ & $\begin{array}{l}\mathbf{0} \\
\text { (R) }\end{array}$ & $\begin{array}{l}10.3 \\
(\mathbf{R})\end{array}$ & $\begin{array}{l}8.6 \\
(\mathbf{R})\end{array}$ & $\begin{array}{l}9.6 \\
(\mathbf{R})\end{array}$ & $\begin{array}{l}8.6 \\
\text { (R) }\end{array}$ & $\begin{array}{l}9.6 \\
\text { (R) }\end{array}$ & $\begin{array}{l}\mathbf{0} \\
(\mathbf{R})\end{array}$ & $\begin{array}{l}\text { O } \\
\text { (R) }\end{array}$ & $\begin{array}{l}\mathbf{0} \\
\text { (R) }\end{array}$ & $\begin{array}{l}\mathbf{0} \\
\text { (R) }\end{array}$ \\
\hline MRP2 & $\begin{array}{l}0 \\
\text { (R) }\end{array}$ & $\begin{array}{l}19.6 \\
\text { (S) }\end{array}$ & $\begin{array}{l}9.6 \\
(\mathrm{R})\end{array}$ & $\begin{array}{l}19.6 \\
\text { (S) }\end{array}$ & $\begin{array}{l}9.6 \\
(\mathrm{R})\end{array}$ & $\begin{array}{l}20.6 \\
\text { (S) }\end{array}$ & $\begin{array}{c}8.6 \\
(\mathrm{R})\end{array}$ & $\begin{array}{l}22.3 \\
\text { (S) }\end{array}$ & $\begin{array}{l}0 \\
\text { (R) }\end{array}$ & $\begin{array}{l}19.6 \\
\text { (S) }\end{array}$ & $\begin{array}{l}10.6 \\
\text { (R) }\end{array}$ & $\begin{array}{l}23.3 \\
\text { (S) }\end{array}$ & $\begin{array}{l}0 \\
(\mathrm{R})\end{array}$ & $\begin{array}{l}19.3 \\
\text { (S) }\end{array}$ & $\begin{array}{l}0 \\
(\mathrm{R})\end{array}$ & $\begin{array}{l}18.8 \\
\text { (S) }\end{array}$ & \begin{tabular}{|l}
0 \\
(R)
\end{tabular} & $\begin{array}{l}23.6 \\
\text { (S) }\end{array}$ & $\begin{array}{l}9.6 \\
\text { (R) }\end{array}$ & $\begin{array}{l}24.3 \\
\text { (S) }\end{array}$ & $\begin{array}{l}8.6 \\
\text { (R) }\end{array}$ & $\begin{array}{l}22.9 \\
\text { (S) }\end{array}$ & $\begin{array}{l}0 \\
(\mathrm{R})\end{array}$ & $\begin{array}{l}19.3 \\
\text { (S) }\end{array}$ \\
\hline MRP3 & $\begin{array}{l}0 \\
\text { (R) }\end{array}$ & $\begin{array}{l}18.6 \\
(\mathrm{~S})\end{array}$ & $\begin{array}{l}0 \\
\text { (R) }\end{array}$ & $\begin{array}{l}19.6 \\
(\mathrm{~S})\end{array}$ & $\begin{array}{l}0 \\
\text { (R) }\end{array}$ & $\begin{array}{l}20.3 \\
(\mathrm{~S})\end{array}$ & $\begin{array}{l}9.6 \\
(\mathrm{R})\end{array}$ & $\begin{array}{l}18.9 \\
\text { (S) }\end{array}$ & $\begin{array}{l}0 \\
\text { (R) }\end{array}$ & $\begin{array}{l}19.6 \\
(\mathrm{~S})\end{array}$ & $\begin{array}{l}8.6 \\
\text { (R) }\end{array}$ & $\begin{array}{l}19.6 \\
(\mathrm{~S})\end{array}$ & $\begin{array}{l}0 \\
\text { (R) }\end{array}$ & $\begin{array}{l}20.3 \\
(S)\end{array}$ & $\begin{array}{l}0 \\
\text { (R) }\end{array}$ & $\begin{array}{l}19.6 \\
\text { (S) }\end{array}$ & $\begin{array}{l}9.6 \\
\text { (R) }\end{array}$ & $\begin{array}{l}23.6 \\
\text { (S) }\end{array}$ & $\begin{array}{l}10.3 \\
\text { (R) }\end{array}$ & \begin{tabular}{|l}
24.3 \\
(S)
\end{tabular} & $\begin{array}{l}9.6 \\
\text { (R) }\end{array}$ & $\begin{array}{l}23.9 \\
\text { (S) }\end{array}$ & $\begin{array}{l}0 \\
\text { (R) }\end{array}$ & $\begin{array}{l}19.6 \\
\text { (S) }\end{array}$ \\
\hline MRP4 & $\begin{array}{l}0 \\
\text { (R) }\end{array}$ & $\begin{array}{l}19.6 \\
(\mathrm{~S})\end{array}$ & $\begin{array}{l}0 \\
\text { (R) }\end{array}$ & $\begin{array}{l}18.6 \\
(\mathrm{~S})\end{array}$ & $\begin{array}{l}0 \\
\text { (R) }\end{array}$ & $\begin{array}{l}22.3 \\
\text { (S) }\end{array}$ & $\begin{array}{l}6.3 \\
(\mathrm{R})\end{array}$ & $\begin{array}{l}19.6 \\
\text { (S) }\end{array}$ & $\begin{array}{l}0 \\
\text { (R) }\end{array}$ & $\begin{array}{l}18.9 \\
\text { (S) }\end{array}$ & $\begin{array}{l}9.6 \\
\text { (R) }\end{array}$ & $\begin{array}{l}20.6 \\
\text { (S) }\end{array}$ & $\begin{array}{l}0 \\
\text { (R) }\end{array}$ & $\begin{array}{l}19.6 \\
\text { (S) }\end{array}$ & $\begin{array}{l}9.6 \\
(\mathrm{R})\end{array}$ & $\begin{array}{l}24.6 \\
\text { (S) }\end{array}$ & $\begin{array}{l}6.9 \\
\text { (R) }\end{array}$ & $\begin{array}{l}21.6 \\
\text { (S) }\end{array}$ & $\begin{array}{l}9.6 \\
\text { (R) }\end{array}$ & \begin{tabular}{|l} 
\\
23.6 \\
(S)
\end{tabular} & \begin{tabular}{|l}
0 \\
(R)
\end{tabular} & $\begin{array}{l}24.6 \\
\text { (S) }\end{array}$ & \begin{tabular}{|l} 
\\
$(\mathrm{R})$
\end{tabular} & $\begin{array}{l}18.6 \\
\text { (S) }\end{array}$ \\
\hline MRS5 & $\begin{array}{l}\mathbf{0} \\
\text { (R) }\end{array}$ & $\begin{array}{l}9.6 \\
(\mathbf{R})\end{array}$ & $\begin{array}{l}6.3 \\
\text { (R) }\end{array}$ & $\begin{array}{l}9.6 \\
(\mathbf{R})\end{array}$ & $\begin{array}{l}\mathbf{0} \\
\text { (R) }\end{array}$ & $\begin{array}{l}9.3 \\
(\mathbf{R})\end{array}$ & $\begin{array}{l}\mathbf{0} \\
\text { (R) }\end{array}$ & $\begin{array}{l}8.6 \\
\text { (R) }\end{array}$ & $\begin{array}{l}\text { 0 } \\
\text { (R) }\end{array}$ & $\begin{array}{l}\mathbf{0} \\
\text { (R) }\end{array}$ & $\begin{array}{l}\mathbf{0} \\
\text { (R) }\end{array}$ & $\begin{array}{l}10.3 \\
\text { (R) }\end{array}$ & $\begin{array}{l}\text { 0 } \\
\text { (R) }\end{array}$ & $\begin{array}{l}\text { O } \\
\text { (R) }\end{array}$ & $\begin{array}{l}\mathbf{0} \\
(\mathbf{R})\end{array}$ & $\begin{array}{l}9.3 \\
(\mathbf{R})\end{array}$ & $\begin{array}{l}6.3 \\
(\mathbf{R})\end{array}$ & $\begin{array}{l}9.6 \\
(\mathrm{~S})\end{array}$ & $\begin{array}{l}\mathbf{0} \\
\text { (R) }\end{array}$ & $\begin{array}{l}\mathbf{0} \\
\text { (R) }\end{array}$ & $\begin{array}{l}9.6 \\
(\mathbf{R})\end{array}$ & $\begin{array}{l}10.3 \\
\text { (R) }\end{array}$ & $\begin{array}{l}\mathbf{0} \\
\text { (R) }\end{array}$ & $\begin{array}{l}\mathbf{0} \\
\text { (R) }\end{array}$ \\
\hline MRP6 & $\begin{array}{l}0 \\
\text { (R) }\end{array}$ & $\begin{array}{l}19.6 \\
(S)\end{array}$ & $\begin{array}{l}0 \\
\text { (R) }\end{array}$ & $\begin{array}{l}18.6 \\
(\mathrm{~S})\end{array}$ & $\begin{array}{l}0 \\
(\mathrm{R})\end{array}$ & $\begin{array}{l}22.3 \\
(\mathrm{~S})\end{array}$ & $0(\mathrm{R})$ & $\begin{array}{l}21.6 \\
(\mathrm{~S})\end{array}$ & $\begin{array}{l}0 \\
\text { (R) }\end{array}$ & $\begin{array}{l}19.3 \\
(\mathrm{~S})\end{array}$ & $\begin{array}{l}6.3 \\
(\mathrm{R})\end{array}$ & $\begin{array}{l}20.3 \\
(\mathrm{~S})\end{array}$ & $\begin{array}{l}0 \\
\text { (R) }\end{array}$ & $\begin{array}{l}19.6 \\
\text { (S) }\end{array}$ & $\begin{array}{l}9.6 \\
(\mathrm{R})\end{array}$ & $\begin{array}{l}19.6 \\
(\mathrm{~S})\end{array}$ & $\begin{array}{l}9.6 \\
\text { (R) }\end{array}$ & $\begin{array}{l}23.3 \\
(\mathrm{~S})\end{array}$ & $\begin{array}{l}9.3 \\
(\mathrm{R})\end{array}$ & $\begin{array}{l}22.6 \\
\text { (S) }\end{array}$ & \begin{tabular}{|l}
0 \\
$(\mathrm{R})$
\end{tabular} & $\begin{array}{l}19.6 \\
\text { (S) }\end{array}$ & $\begin{array}{l}0 \\
\text { (R) }\end{array}$ & $\begin{array}{l}19.6 \\
(\mathrm{~S})\end{array}$ \\
\hline
\end{tabular}

BC- Before curing, AC-After curing, R- resistance, S-sensitive, MRP1-Multi- drug resistance Proteus vulgaris 1, MRP2- Multi- drug resistance Proteus vulgaris 2, MRP3- Multi- drug resistance Proteus vulgaris 3, MRP4- Multi- drug resistance Proteus vulgaris 4, MRS5- Multi- drug resistance Salmonella typhi, MRP6Multi- drug resistance Proteus vulgaris 6 
Pre and Post curing sensitivity of bacterial isolates from food, human and chicken (black layers)

\begin{tabular}{|c|c|c|c|c|c|}
\hline \multirow[t]{2}{*}{ Isolates } & \multirow[t]{2}{*}{ Sources of sample } & \multirow{2}{*}{$\begin{array}{l}\text { Plasmid } \\
\text { bands }\end{array}$} & \multirow{2}{*}{$\begin{array}{l}\text { Molecular } \\
\text { Weight } \\
\text { (bp) }\end{array}$} & \multicolumn{2}{|l|}{ Ampicillin } \\
\hline & & & & $\begin{array}{l}\text { Before curing } \\
(\mathbf{m m})\end{array}$ & $\begin{array}{l}\text { After curing } \\
(\mathbf{m m})\end{array}$ \\
\hline E1 & Sick human & Single & 23,130 & $0(\mathrm{R})$ & $18.3(\mathrm{~S})$ \\
\hline E3 & sick human & Triple & $\begin{array}{l}2,322 \\
6,557 \\
23,130\end{array}$ & $0(\mathrm{R})$ & $18.6(\mathrm{~S})$ \\
\hline E4 & Sick human & Single & 23,130 & $0(\mathrm{R})$ & $19.6(\mathrm{~S})$ \\
\hline E5 & Sick human & Single & 23,130 & $0(\mathrm{R})$ & $19.3(\mathrm{~S})$ \\
\hline E7 & Sick human & Single & 23,130 & $\mathbf{0}(\mathbf{R})$ & $\mathbf{0}(\mathbf{R})$ \\
\hline E8 & Sick human & Single & 23,130 & $0(\mathrm{R})$ & $20.3(\mathrm{~S})$ \\
\hline E9 & Sick human & Single & 23,130 & $0(\mathrm{R})$ & $19.3(\mathrm{~S})$ \\
\hline E10 & Sick human & Single & 23,130 & $\mathbf{0}(\mathbf{R})$ & $\mathbf{O}(\mathbf{R})$ \\
\hline E11 & Sick human & Single & 23,130 & $0(\mathrm{R})$ & $20.3(\mathrm{~S})$ \\
\hline E12 & Sick human & Single & 23,130 & $8.3(\mathrm{R})$ & $19.6(\mathrm{~S})$ \\
\hline E14 & Food & Single & 23,130 & $6.3(\mathrm{R})$ & $22.6(\mathrm{~S})$ \\
\hline E15 & Food & Single & 23,130 & 7.6(R) & $18.3(\mathrm{~S})$ \\
\hline E16 & Food & Single & 23,130 & $4.3(\mathrm{R})$ & $5.6(\mathrm{R})$ \\
\hline E18 & Food & Single & 23,130 & $0(\mathrm{R})$ & $17.6(\mathrm{~S})$ \\
\hline E20 & Food & Single & 23,130 & $0(\mathrm{R})$ & $18.3(\mathrm{~S})$ \\
\hline E21 & Food & Single & 23,130 & $\mathbf{0}(\mathbf{R})$ & $\mathbf{0}(\mathbf{R})$ \\
\hline E22 & Food & Single & 23,130 & $0(\mathrm{R})$ & $22.3(\mathrm{~S})$ \\
\hline E23 & Food & Single & 23,130 & $6.6(\mathrm{R})$ & $18.6(\mathrm{~S})$ \\
\hline $\begin{array}{l}\text { E24 } \\
\text { E25 }\end{array}$ & $\begin{array}{l}\text { Food } \\
\text { Food }\end{array}$ & $\begin{array}{l}\text { Single } \\
\text { Single }\end{array}$ & $\begin{array}{l}23,130 \\
23,130\end{array}$ & $\begin{array}{l}0(\mathbf{R}) \\
8.3(\mathbf{R})\end{array}$ & $\begin{array}{l}\mathbf{0}(\mathbf{R}) \\
9.3(\mathrm{R})\end{array}$ \\
\hline E28 & Apparently healthy human & Single & 23,130 & $0(\mathrm{R})$ & $19.3(\mathrm{~S})$ \\
\hline E29 & Apparently healthy human & Single & 23,130 & $0(\mathrm{R})$ & $20.3(\mathrm{~S})$ \\
\hline P32 & Sick human & Single & 23,130 & $0(\mathrm{R})$ & $21.6(\mathrm{~S})$ \\
\hline P33 & Apparently healthy black layer & Single & 23,130 & $8.6(\mathrm{R})$ & $22.6(\mathrm{~S})$ \\
\hline P34 & Apparently healthy black layer & Single & 23,130 & $0(\mathrm{R})$ & $19.3(\mathrm{~S})$ \\
\hline P35 & Apparently healthy black layer & Single & 23,130 & $0(\mathrm{R})$ & $18.6(\mathrm{~S})$ \\
\hline P36 & Apparently healthy black layer & Single & 23,130 & $9.6(R)$ & $10.6(\mathrm{R})$ \\
\hline P37 & Apparently healthy black layer & Single & 23,130 & $0(\mathrm{R})$ & $18.3(\mathrm{~S})$ \\
\hline P38 & Apparently healthy black layer & Single & 23,130 & $0(\mathrm{R})$ & $22.3(\mathrm{R})$ \\
\hline S40 & Food & Single & 23,130 & $9.6(\mathrm{R})$ & $18.3(\mathrm{~S})$ \\
\hline S41 & Food & Single & 23,130 & $0(\mathrm{R})$ & $19.6(\mathrm{~S})$ \\
\hline S42 & Apparently healthy human & Single & 23,130 & $8.6(\mathrm{R})$ & $23.6(\mathrm{~S})$ \\
\hline S43 & Sick human & Single & 23,130 & 4.6(R) & $5.6(\mathrm{R})$ \\
\hline S44 & Apparently healthy black layer & Single & 23,130 & $0(\mathrm{R})$ & $20.3(\mathrm{~S})$ \\
\hline S45 & Apparently healthy black layer & Single & 23,130 & $0(\mathrm{R})$ & $18.6(\mathrm{~S})$ \\
\hline K48 & Apparently healthy human & Single & 23,130 & $8.3(\mathrm{R})$ & $22.6(\mathrm{~S})$ \\
\hline K49 & Apparently healthy black layer & Single & 23,130 & $0(\mathrm{R})$ & $20.3(\mathrm{~S})$ \\
\hline K50 & Apparently healthy black layer & Single & 23,130 & 7.6(R) & $18.6(\mathrm{~S})$ \\
\hline K51 & Apparently healthy black layer & Single & 23,130 & $0(\mathrm{R})$ & $19.6(\mathrm{~S})$ \\
\hline
\end{tabular}


Plate.1 Photograph showing plasmid profile of some bacterial isolates with multiple resistance from apparently healthy black layers and sick human fecal samples

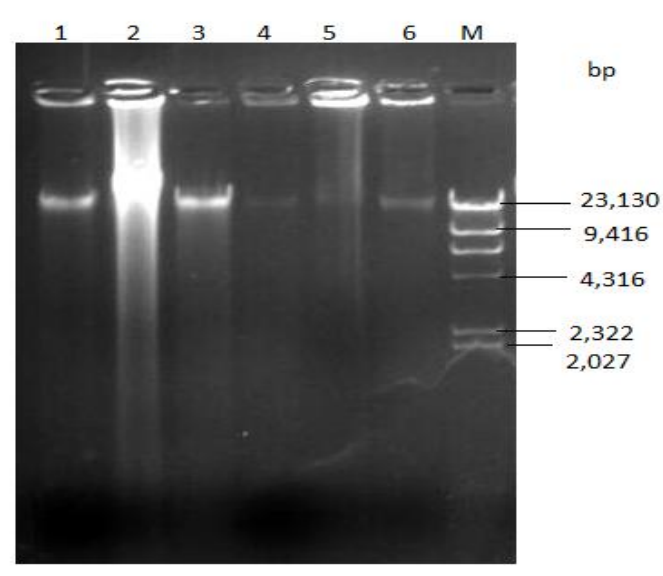

Plate.2 Photograph showing plasmid profile of Escherichia coli isolated from feces of sick human (lane 1-13)

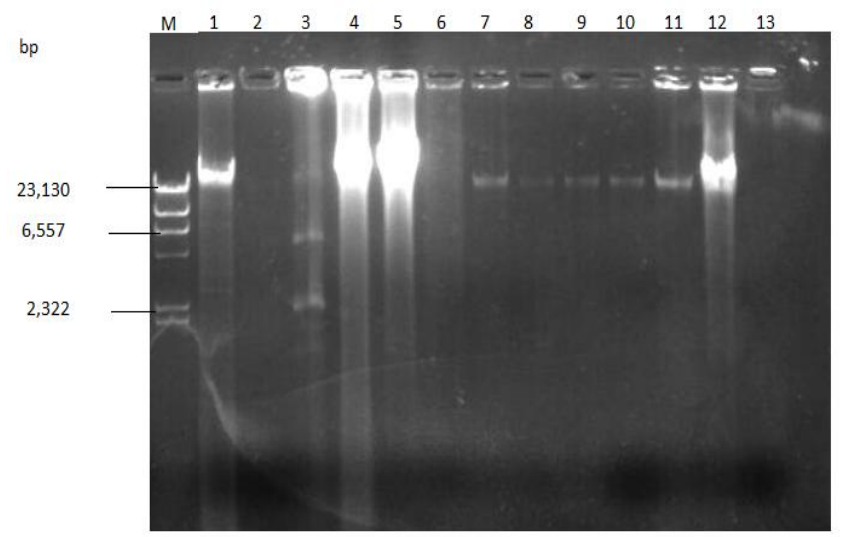

NOTE: Plasmid DNA on 0.8g Agarose, M-Molecular marker Hindalll lambda, lane 47-51(Klebsiella aerogenes)

Bp-Unit of molecular weight is base pair 


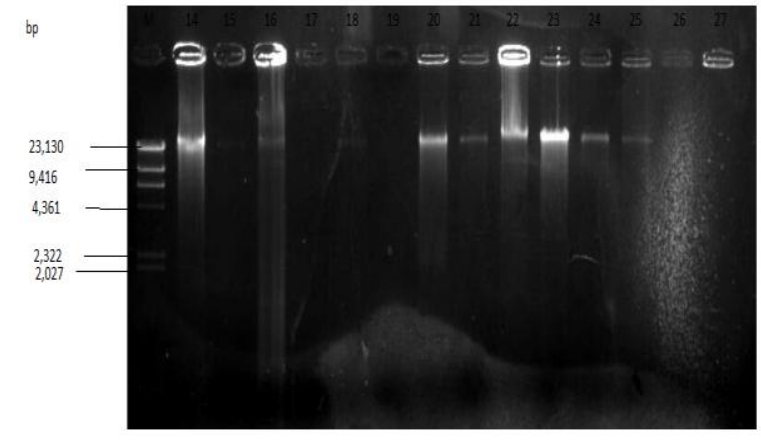

Plate.3 Photograph showing Plasmid profile of Escherichia coli isolated from Food samples (lanes 14-27)

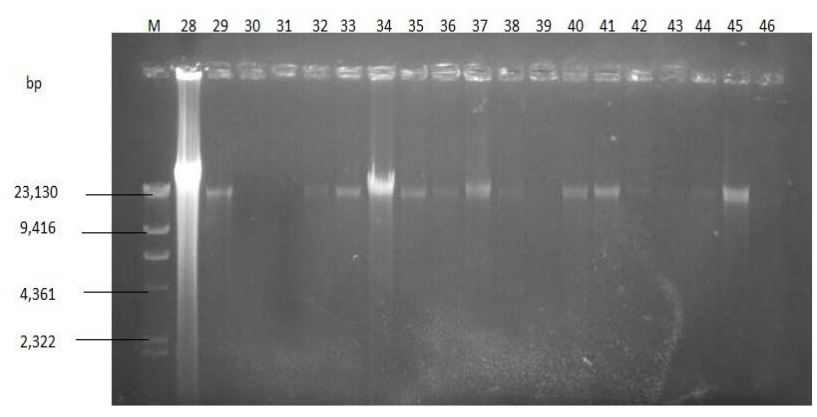

Plate.4 photograph showing plasmid of Escherichia coli from apparently healthy lanes 28-29 and black layers lane 30-31, Proteus vulgaris from the feces of sick human lane 32, apparently healthy black layers lane 33-38, Salmonella typhi from food lanes 39-41, Salmonella typhi from apparently healthy human lane 42 , feces from sick human lane 43 and apparently healthy black layer lane 44-60

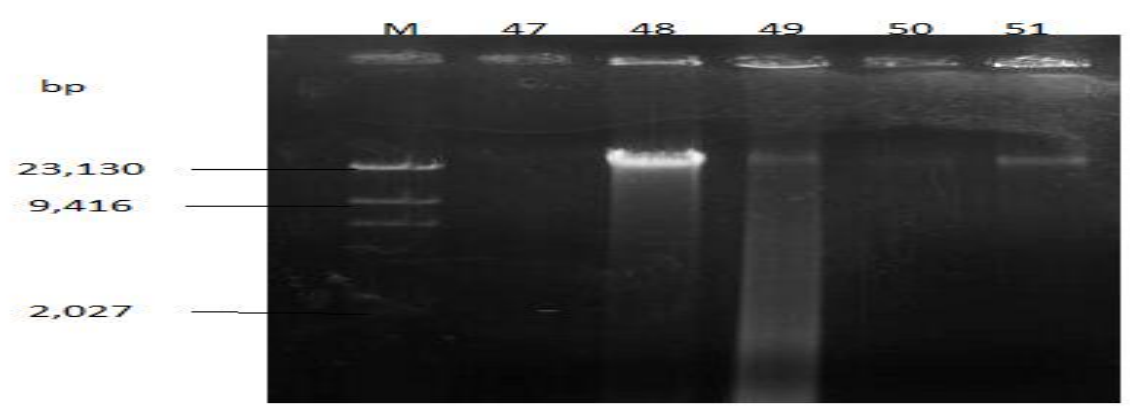

Plate.5 Photograph showing the plasmid profile of ESBL producing Klebsiella aerogenes isolated from faeces of apparently healthy human (lane 47-48) and apparently healthy black layers (lanes 49-51). 
Antibiotic resistance in bacteria has emerged as a medical challenge. This results from the speed at which bacteria multiply and are spread, and the ease with which they can change their genetic material or acquire new genes. They exert biochemical resistance by preventing entry of the drug, by rapidly extruding the drug, or by enzymatically inactivating the drug or altering its molecular target. The presence of antibiotics in the internal environments of human beings and animals provides a selective pressure for any resistant organisms to become predominant.In this study, four different enteric bacteria which include Escherichia coli, Salmonella typhi, Klebsiella aerogenesand Proteus vulgaris were isolated from food, human and chicken (black layers and white broiler) with Escherichia coli predominant in all samples collected

Based on this study, only four members of enteric bacteria i.e. Klebsiella aerogenes, Escherichia coli, Salmonella typhi and Proteus vulgaris were isolated from food, human and apparently healthy chicken (white broiler and black layer). Other bacterial isolated include Staphylococcus aureus and Clostridium botulinum from food and yeast from sick human stool. All the four isolated bacteria are resistant to ampicillin which corroborates the findings of Rahal (2005) which says most strains of Pseudomonas, Klebsiella, Aerobacter, Enterobacter, Citrobacter, Serratia, Salmonella, Escherichia coli andindole-positive Proteus species are considered resistant to Ampicilin (Rahal, 2005).The result from this study show high antimicrobial resistance among the isolates. This resistance had cut across all the isolates regardless of the source as well as the various classes of antibiotics.

The problem of resistance by bacteria to antibiotics continue and if as suggested by (kamrzzaman et al., 2017), hospital managing critically ill patients who are at high risk of being infected, there might need to look into the possibility of using simple oral administrative route of in vivo plasmid curing. This could be the much need light to the threat of antibiotics resistance.

Both Gram-positive and gram-negative disc were used for the antibiotic susceptibility testing. Gram-positive disc which include

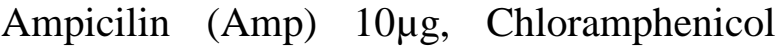
(chl) $10 \mu \mathrm{g}, \quad$ Cloxacillin (Cxc) $5 \mu \mathrm{g}$,

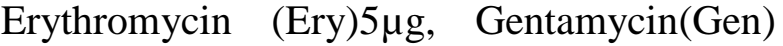

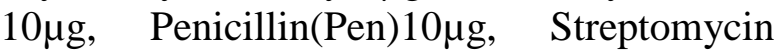
(Str) $10 \mu \mathrm{g}$, Tetracycline (Tet) $10 \mu \mathrm{g}$ disc and Gram-negative disc which include

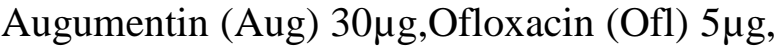

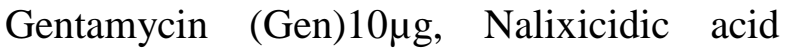

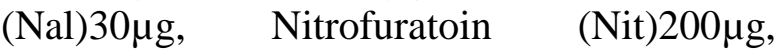
Cotrimazole (Cot) $25 \mu \mathrm{g}$, Amoxicillin (Amx) $25 \mu \mathrm{g}$, Tetracycline (Tet) $25 \mu \mathrm{g}$. This study confirm that Gram-negative disc were more effective in treating infection caused by Gram-negative organism than Gram-positive disc. Based on antibiotic susceptibility testing, only Gentamycin were sensitive to bacterial isolates while other antibiotics were resistance to bacterial isolates. On the other hand, bacterial isolates were sensitive to Nitrofuratoin, Gentamycin, Nalixidic acid, Ofloxacin and Cotrimazole on Gram-negative disc. Therefore Gram-negative disc are more effective in treating ESBL infection than gram-positive disc. Most of all the isolates tested were susceptible to Nitrofuratoin, Nalixicidic acid, Gentamycin, Cotrimazole and Ofloxacin which was in accordance with (Woodfordet al., 2006) which says Treatment options for ESBL infections may include Nitrofuratoin and in desperation, Gentamycin injections may be used.

This study also reports on bacterial isolates that shows multiple resistance to different antibiotics isolated from black layer and sick human. This was observed in Proteus vulgaris 
isolated from black layers and Salmonella typhi isolated from sick human stool. This might be as a result of the use of antibiotics for therapeutic and non -therapeutic purpose among farm animals. Resistance seen in sick human may be as a result of exposure to antibiotics and long time stay in hospital facilities.

Plasmid has been documented to have encoded gene that provides resistance to occurring antibiotics in competitive environmental niche (Kroll et al., 2010). This study confirms that most resistance in this study was plasmid mediated. The isolates involved carried plasmid whose molecular weight ranged from 2,322bp $(2.3 \mathrm{~kb})$ and $23,130 \mathrm{bp}(23 \mathrm{~kb})$ with exception seen in some isolates which showed no plasmid bands. Kroll et al. (2010) reported that plasmid mediated mechanism may increase the likehood of horizontal spread of resistance. Resistance to bacterial organism not due to plasmid might be due to the efflux mechanism (Poole, 2004). Plasmid profile of Escherichia coli isolated from sick human stool from (lane 1-27) lane $1,4,5,7,8,9,10,11,12,14,15$, $16,18,20,21,22,23,24,25$ have similar plasmid of $23,130 \mathrm{bp}$ with exception of three different bands in lane 3 with plasmid band of 2,322bp ,6557bp and 23,130bp. No plasmid band was seen in lane 2, 6, 13, 17, 19, 26 and 27 indicating that the isolates did not contain plasmid. The chance that plasmid found in food sold in canteen is worrisome and underscoring the sanitary status of the food handlers and probably cooking processors. The plasmid profile of Escherichia coli from apparently healthy human stool from lanes 28-29 showed same plasmid band with molecular weight of 23,130bp. Escherichia coli from sick black layer in lane 30 and 31 showed no plasmid. Proteus vulgaris isolated from sick human stool (lane 32), apparently healthy black layer (lane 33-38), Salmonella typhi from food (lane 39-41), apparently human stool (lane 42), sick human stool (lane 43) and apparently black layer (lane 44-45) have molecular weight of $23,130 \mathrm{bp}$ with exception seen in lane 46 with no plasmid band. Plasmid profile of Klebsiella aerogenes isolated from apparently healthy human stool in lane 48 is $23,130 \mathrm{bp}$ with no plasmid in lane 47 and Klebsiella aerogenes from black layer from lane 49, 50 and 51 with molecular weight of $23,130 \mathrm{bp}$.

Plasmid has been documented to have encoded gene that provides resistance to naturally occurring antibiotics in competitive environmental niche (Lipps, 2008; krollet al., 2010). Findings from this study indicated that resistance shown by the bacterial isolates is mainly plasmid mediated. In addition, some of the bacterial isolates are chromosomal mediated. Although, most of the bacterial isolates carried plasmid bands but not all are responsible for the antibiotics resistance.. This is supported by (Thomas et al., 1998) who reported that plasmid mediated mechanism may increase the like hood of horizontal spread. Resistance of bacterial organism not due to plasmid or chromosome might be due to efflux pump mechanism (Poole, 2004) or other factors like mutation of genes encoding ribosomal protein which decrease permeability of the cell envelope in enteric bacteria (Isenerger et al., 2002). There is therefore no doubt that ESBL producing bacterial isolates can be found in food, human and chicken especially black layers in Ekiti State, Nigeria.

\section{Contributions of study to knowledge}

This research has been able to establish that:

Antibiotics resistance to ampicillin was high among the enteric bacteria isolated from food, human and chicken in Ekiti state;

The most effective antibiotics against ESBL 
producing bacterial isolated are Nalixidic acid and Nitrofuratoin;

Resistance can be plasmid mediated or chromosomally mediated

Conclusion and Recommendations are as follows:

The fact that prevalence rates are rising globally, including in nonhospital settings, food, apparently healthy and sick subject, among chickens and even fish farming where chicken stool are used as fertilizer to boast the growth of fish is of great concern to public health at large. However, this study has revealed findings concerning $\beta$-lactamases producing organism isolated from food, human and apparently healthy chicken especially black layer.

Therefore, appropriate antimicrobial selection, personal hygiene and quality control should be encouraged in canteens, personal hygiene among health workers, proper diagnosis to ascertain the causative agent before prescription, ban the use of antibiotics in farm animals, over the counter prescription should totally be avoided, professional pharmacist should be employed and effective infection control procedures are the key partners in their control.

\section{Recommendations}

The problem of antibiotics resistance in bacterial pathogens is a great concern to public health. It is important to recall that antibiotics resistance profile and sensitivity profile in this study is to provide an updated data for clinician, Medical laboratory scientist and other health care workers in order to facilitate the use of appropriate and more effective treatment regimes. However, in order to curb the menace of antibiotic resistance, indiscriminate use of antibiotics and over-the-counter sales of antibiotics should be discouraged. In addition, the use of antibiotics among poultry farm should be regulated with caution.

Also, regular monitoring of restaurants by the relevant agencies should not be overlooked. It has been noted that more research had been carried out on plasmid mediated resistance of enteric bacteria to antibiotic, effort should be made to research on the chromosomal mediated resistance of Enterobacteriaceae to antibiotics as reports on this aspect is limited.

Above all, accelerated and continuous search for alternative remedy and more effective new antibiotics should be increased. The use of antibiotics among farm animals should be regulated. However, antibiotics in this part of the world are still very important.

Gentamycin, Nitrofuratoin, Nalixidic acid, Cotrimazole and Ofloxacin can be adopted in the treatment of ESBLs infection based on the findings from this study. Nitrofuratoin and Nalixidic acid should be adopted in the treatment of ESBL infection as these have the highest sensitivity rate in this environment. Also combination of more than one drug (synergy drugs) can be effective. Although, there is need for antibiotics sensitivity pattern and Double Disk Synergy Test (DDST) to be routinely performed on ESBLs infected patients or hospital patients at large before prescriptions.

Plasmid curing and plasmid profile procedure should be used and considered for antibiotics resistance to determine if resistance is plasmid mediated or chromosomally mediated

\section{References}

Annika, D., Sayali, N., Meeta, B., Jossy, V., Naresh, C. (2013). Plasmid curing and protein profiling of heavy metals 
tolerating bacterial isolates. . Scholar Research Library. Archive of Applied Science Research ,5(4):46-54.

Bennett, P. M. (2008). Plasmid encoded antibiotic resistance: acquisition and transfer of antibiotic resistance genes in bacteria. British Journal of Pharmacology, 153 (1): 347-357.

Bergenholtz, R .D., Jorgensen, M. S., Hansen, L. H., Jensen, L.B., and Hasman, H. (2009). Characterization of genetic determinants of extended-spectrum cephalosporinases (ESCs) in Escherichia coli isolates from Danish and imported poultry meat. Journal of Antimicrobial Chemotherapy, 64: 207209.

Bonnet, R. (2004). Growing group of extended-spectrum $\beta$-lactamases: the CTX-M enzymes. Antimicrobial Agents and Chemotherapy, 48(1):1-14.

Bush, K. (2008). Extended-spectrum $\beta$ lactamases in North America, 19872006. Clinical Microbiology and Infection, 14(1):134-143.

Bush, K., and Jacoby, G.A. (2010). Updated functional classification of betalactamases. Antimicrobial Agents Chemotherapy, 54: 969-976.

Carattoli, A. (2008). Animal reservoirs for extended spectrum beta-lactamase producers. Clinical Microbiology Infection, 14:117-123

Charles, O.E., Chukwuemeka, S. N., and Gugu, T.H.(2010). Antibiogram and plasmid profile of some multiantibiotics resistant urinopathogens obtained from local communities of Southeastern, Nigeria. Journal of Medicine and Biomedical sciences, 2(4):152-159.

Clinical and Laboratory Standards Institute (2015). Performance standards for antimicrobial/susceptibility tests, Wayne, PA: CLSI.

Ekundayo .O.K and Onifade A.K, (2020).
Detection of Beta Lactamase in Ampicillin Resistance Enterobacteriaceae isolated from Human stool In Ekiti state

Ezekiel, C. N., Olarinmoye, A. O., Oyinloye, J. M., A, Olaoye, O. B. and Edun, A. O. (2011). Distribution, Antibiogram and multidrug resistance in Enterobacteriaceae from commercial poultry feeds in Nigeria. African Journal of Microbiology Research, 5(3):294-301.

Furtini, D., Fashae, K., Garcia-fernado, A., Villa, Z., and Carattoli, A.( 2011). Plasmid mediated quinolones and $\beta$ lactamase in Escherichia coli from healthy animals from Nigeria. Journal of Antimicrobial Chemotherapy. (6):69-72.

Kamruzzaman M. shoma S, Thomas C.M., Patridge S.R, Iredell J.R. Plasmid interference for curing antibiotics resistance for curing antibiotics resistance plasmid in vivo.PLoS ONE $2017 ; 12$

Mayer, L.W., 1988 use of plasmid profiles in epidemiologic surveillance of disease outbreaks in tracing the transmission of antibiotics' resistance. Clinical Microbiology Reviews .1988 April 1(2):228-243.doi:10.1128/cmr.1.2.228

Mesa, R., Blanc, V., Saco, M., Lavilla, S., Prats, G., Miro, E., Navarro, F., Cortes, P, and Llagostera, M. (2006). ESBLand plasmid class $\mathrm{C}$ beta-lactamaseproducing $E$. coli strains isolated from poultry, pig and rabbit farms. Vetinary Microbiology, 118: 299-304.

Mesa, R., Blanc, V., Saco, M., Lavilla, S., Prats, G., Miro, E., Navarro, F., Cortes, P, and Llagostera, M. (2006). ESBLand plasmid class $\mathrm{C}$ beta-lactamaseproducing E. coli strains isolated from poultry, pig and rabbit farms. Vetinary Microbiology, 118: 299-304.

Ochei, J. and Kolkhtar, A. (2000). 
Bacteriology: Medical Laboratory Science, theory and practice. In: Bulakh P.M and Deshmukh S.(eds). Tata McGraw-Hill publishing company limited New Delhi. PP. 525-752

Paterson, D. L., and Bonomo, R. A., (2005). Extended-spectrum beta-lactamases: a clinical update. Clinical Microbiolology, 18: 657-686

Plasmid http://biologydictionary.net/plasmid/ Rahal,, J.J. (2005). Extended spectrum Blactamases: how big is the
problem?.Clinical

Infection; 6: 2-6.

Splengler, G., Molnar, A., Schelz, Z., Amaral, L., Sharpless, D., and Molnar, J.(2006). The mechanism of plasmid curing in bacteria. Current Drug target, 7(7): 823-841.

Vlab,amrita.edu., (2011).plasmid curing.retrieved 7 May 2020 from vlab.amrita.edu/? $\mathrm{sub}=3 \& \mathrm{brch}=186 \& \operatorname{sim}=1097 \& \mathrm{cnt}=6$

\section{How to cite this article:}

Ekundayo, O. K. 2021. Plasmid Profile and Plasmid Curing of Some Enterobacteriaceae Resistant to Ampicillin Isolated from Food, Human Stool, Chicken Stool in Ekiti State. Int.J.Curr.Microbiol.App.Sci. 10(01): 2344-2362.

doi: https://doi.org/10.20546/ijcmas.2021.1001.272 